\title{
A Report of the Impacts of Pollutants on Maritime Operation in Vietnam
}

\author{
Xuan Phuong Nguyen, Van Huong Dong
}

\begin{abstract}
The article focuses on synthesis and production of adsorbents to collect oil spills using available and surplus raw materials in agriculture. Research on the manufacture of oil sorbent based on the combination of polyurethane and agricultural by-product is conducted. Nowadays, waste byproducts are partly composted, partly used as feed for the remaining cattle that is disposed of in the environment or burned out. This wall is the cause of severe environmental pollution. Therefore, using this waste straw combined with polyurethane to make oil absorbing materials to treat oil pollution at sea is a feasible, scientific and practical option, contributing to minimizing environmental pollution as well as promoting the development of agriculture. Thus, with the current strategy of marine economic development and strong waterway transportation, it will lead to serious environmental pollution if we need specific solutions to solve the problem of neglect. Application of adsorbent material to absorb oil and heavy metals from waste water of transport fleet is part of the strategy of sustainable economic development.
\end{abstract}

Index Terms-Maritime Operation; Pollutant Pollution; Oil Spill; Absorbent; Heavy Metal.

\section{INTRODUCTION}

In the era of industrialization and modernization taking place everywhere in the world today, the demand for energy is enormous. Consequently, fuel and energy savings are always a top priority for every country and every industry, especially the automotive industry, which requires a change of day [1],[2]. The solution is a flexible combination of gasoline engines, electric motors and mechanisms that help conserve and convert energy efficiently. Nowadays, the rapid development of vehicles, especially in urban areas, causes serious air pollution caused by emissions from automobile engines [3]. The problem of environmental pollution is one of the problems of many countries today. The Vietnam Sea connects the Pacific Ocean and An Duong Duong, acting as one of the major navigable highways, of which about $70 \%$ are oil tankers and oil products [4]. Annually, about 200 million tons of oil are transported through the waters off Vietnam from the Middle East to East Asia. Offshore oil and gas exploration and exploitation activities increase annually. The South China Sea has become one of the most active oil and gas exploration and production sites in the region and in the world. Vietnam has about 60 seaports of different sizes, mainly in Hai Phong Quang Ninh, Ho Chi Minh City - Vung Tau - Thi Vai. At present and in the future, due to the economic development and growth of the shipping industry, many ports and

Published on October 30, 2018.

X. P. Nguyen and V. H. Dong are with Ho Chi Minh city University of Transport, Ho Chi Minh city, Vietnam. shipyards will be built and expanded.

However, when the marine industry develops, the problem of pollution of the marine environment is getting worse [5]. The pollution impacts of waterway transportation are varied and can be divided into impact groups including pollution from water transport facilities, from port construction and operation and from the newbuilding industry. ship-to-ship, cargo, waste water, waste, flue gas, ballast water or ship's anti-ship system; In particular, oil pollution is a major risk, affecting the ecosystem of aquatic animals and plants in the contaminated area, causing loss of catch, aquaculture and other industries (travel ...). It is estimated that in recent times, the amount of oil spilled into the sea was about 3.2-6.1 million tons/year, equivalent to $0.2-0.3$ of total oil shipped by sea in 1980 and equal to $0.1-$ 0.2 oil exploited worldwide.

Water navigation activities include the operation of means of sea traffic, river transport and onshore supporting industries such as ports, anchorage, transshipment, ship repair facilities and facilities on the set. The environmental impact of oil on shipping operations is greatest because of the enormous amount of oil transported by waterways, which is also the primary fuel for waterborne transportation and delivery vehicles [6]. Information, queues operating in ports. Petroleum is a very complex mixture, in which the main constituents are hundreds of different types of hydrocarbons [7]. Each type of oil is characterized by its own composition, but generally is a comparative liquid, which has a characteristic odor, is slightly lighter than water and is very difficult to dissolve in water. Basic components of the oil include: straight hydrocarbon: 30-35\%; Cyclic hydrocarbons: 30-60\%; Aromatic hydrocarbons: 10\%- $20 \%$ [8]. There are also compounds containing oxygen, sulfur, nitrogen ...For the maritime industry, the most known source of pollution is from tanker-related accidents [9]. Many measurements have been made to determine the amount of oil discharged into the ocean every year, and it is estimated that oil pollution from oil tanker accidents is about $12 \%$. The consequences of the accident can be very serious in the area of the accident, especially in case of a large vessel and near-shore accident [10]. Oil contamination and oil spills, despite the $0.1 \mathrm{mg} / \mathrm{l}$ oil content in the water, can also cause zooplankton mortalities and greatly affect the juveniles and larvae of marine organisms [11]. However, our country's inland water has a constant concentration of water in the water that exceeds the permissible limit of 100-300\% [12]. A recent report by the Ministry of Natural Resources and Environment showed that areas with high levels of oil are the water surface of ports with an oil content of $0.3-0.6 \mathrm{mg} /$ 1 , exceeding the permitted level [13]. Marine pollution in a large seaport is caused by the fact that most of fishing boats, 
cruise ships, military vessels regularly wash ships, dispose of engine oil, ballast water, directly discharge waste water and oil into the sea [14]. All wastes pollute the coastal waters, pollute the oil and pollute heavy metals in the areas of shipyards and docks [15]. They alter the physical and chemical nature of seawater, damaging to marine fauna and flora, salt production, aquaculture and marine tourism. Most ships have no oil and waste water collection and treatment facilities, while Marpol conventions for ships entering or leaving the port are forbidden, and all ships are discharged into the port waters [16].

Nationwide, there are approximately 4 million tons of petroleum fuel from over 1,700 transport ships and about 130,000 fishing vessels per year in Vietnam, which is the source of pollution in coastal areas and in many places [17]. Serious damage to marine ecosystems, damage to marine resources, endangering human health. Research into new materials with high oil absorption capacity, low cost to process oil spills or waste oil pollution is a matter of great urgency and has scientific and practical implications. high fees [18]. The world has made a lot of research into the manufacture and application of polyurethane-based absorbers to tackle oil spills as well as oil pollution at sea. In addition, there are many researches on the absorption of lignocellulosic material from plant biomass, mainly of agricultural and forestry by-products. At present, there are some researches on synthesis of oil absorbing materials such as oil spill collection material using $\mathrm{Fe} 3 \mathrm{O} 4$ nanoparticles or organic materials but still in experimental stage.

\section{CAuse of Oil Pollution}

Environmental impacts from a seagoing vessel can be attributed to the ship's oil, cargo, waste water, waste, exhaust gas, ballast water.

\section{A. Oil pollution}

The environmental impact of oil on shipping operations is greatest because of the enormous amount of oil transported by waterways, which is also the primary fuel for waterborne transportation and delivery vehicles. Information, queues operating in ports [19]. Oil is released into the environment for many reasons:

- From engine cooling water, along with fuel falling from transportation means such as ships or land vehicles operating at ports discharged into rivers and sea. These types of water contain a large amount of gasoline, oil and grease that pollute river and sea water

- Oil spills, collisions between ships, due to bad weather, break oil spills into the sea or incidents during fuel supply, port operations, etc. Oil spills on the sea will spread across different areas due to waves, tides or large ocean currents.

- Water washing tanker cargo

Petroleum is a very complex mixture, in which the main constituents are hundreds of different types of hydrocarbons. Each type of oil is characterized by its own composition, but generally is a comparative liquid, which has a characteristic odor, is slightly lighter than water and is very difficult to dissolve in water. Petroleum in different regions has different chemical compositions. Hydrocarbons are the major constituents of oil, almost all types of hydrocarbons are present in the oil. By means of chemical methods, more than 400 different types of hydrocarbons are identified, divided into paraffin, naphten, aromat and naphten-aromat. Crude oil in Vietnam is a heavy medium heavy, solid paraffin (n-paraffin with a carbon number equal to or greater than 18) and less sulfur.

For the maritime industry, the most known source of pollution is from tanker-related accidents. Many measurements have been made to determine the amount of oil discharged into the ocean every year, and it is estimated that oil pollution from oil tanker accidents is about $12 \%$. The consequences of the accident can be very serious in the area of the accident, especially in case of a large vessel and near-shore accident. In 1974-1989 there were 774 accidents in which the oil spilled into the sea more than 7 tons [20]. Two large oil spills have been cited as a result of the ship's collision with the Amoco Cadiz, which spilled 230,000 tonnes of oil off the coast of Brittany, France in 1978 and the Exxon Valdez accident that contaminated southern Prince William, Alaska in 1989 with 40,000 tons of oil. The most common pollution occurrences occur during ship operation at oil ports when receiving or returning cargo. According to statistics from the International Association of Shipowners, this oil accounts for about $92 \%$ of the total oil spill. Very large amounts of oil are discharged into the sea from normal operations of ships, especially those related to the cleaning of the cargo hold when the ship departs from the port of discharge to another port, preparing to receive new cargo. The amount of oil in the rinse water is about 0.35 of the ship's cargo.

TABLE I: ACCIDENTS CAUSED BY OIL TRANSPORT BY SEA RESULTING IN OIL SPILL OVER 100,000 TONS (AS OF 1997)

\begin{tabular}{cccc}
\hline \hline Year & Ship name & $\begin{array}{c}\text { Location of } \\
\text { accident }\end{array}$ & Oil spill mass \\
\hline 1967 & Torrey Canyon & England & 123.000 \\
1972 & Texanita/Oswego G. & South Africa & 100.000 \\
1976 & Urquiola & Spain & 100.000 \\
1978 & Amoco Cadiz & France & 230.000 \\
1979 & Atlantic Empress & Trinidad & 184.000 \\
1983 & Castillo de Bellver & South Africa & 295.000 \\
1991 & ABT Summer & Angola & 265.000 \\
1991 & Haven & Italia & 140.000 \\
\hline \hline
\end{tabular}

Other sources of oil pollution from the ship, including cargo bay cleaning, are activities when delivering ships in the momentum, when refueling and operating in relation to lacustrine water (for dry cargo ships). oil tankers) and accidents of ships not oil tankers.

\section{B. Pollution caused by goods}

Over $80 \%$ of the world's merchandise is shipped by sea, with a wide variety of highly toxic cargoes such as liquid and bulk cargoes, bulk cargoes Hazardous packaging in the package. For liquid toxins carrying the bucket, the risk of contamination derives from leaks during handling, discharge from marine accidents and disposal of residues during storage and in storage [21]. Dump for maintenance, repair. For liquid volatile liquids such as petroleum and v products, the amount of vapor that blows into the atmosphere cannot be removed, due to the presence of condensed vapors, when the temperature changes of slight modification of the 
mandrel to discharge the vapor to maintain proper pressure to protect the structure [22]. The supply chain will also have an excess of steam produced because the air in the storage tank is replaced by a dump, due to leaks from the dredger.

The commodity category is vegetable oil, whale oil or other food oils, although they do not account for a large proportion, but if spilled into the environment outside of the same effects as oil, to increase water pollution. Bulk cargoes often contaminate water or land by accident on means of transport, due to the discharge of residues from ship cleaning, landfill storage, and pollution. the odor in the process of making goods, some of the goods are toxic gas or evaporate air pollution [23]. Harmful items packed in the package can also cause contamination by dropping the container when the container has been ruptured, or by the container itself, after it has been removed but not properly cleaned.

\section{Waste water pollution}

Wastewater from water transport vehicles is a major source of pollution. They include two groups:

- Wastewater from toilets, from the blackwater: This type of water may contain harmful bacteria, pathogens, viruses, intestinal parasites and harmful substances. The discharge of these wastewater without treatment or inadequate treatment can contaminate water sources and aquatic resources which cause harm to public health. Nutrients in wastewater such as nitrogens and phosphorus increase the growth of algae that reduces oxygen in the water causing death of aquatic organisms and can damage other aquatic resources. A cargo ship with 20 crew members daily emits tons of waste water, especially passenger vessels, a cruise ship carrying 3,000 people daily emitting 6 to 10 tons of waste water.

- Wastewater from bathrooms, cafeterias, laundry rooms and sanitation activities on board. This water contains many different pollutants including coliforms, detergents, grease, metals, organic matter, petroleum, nutrients, food waste, medical waste. This type of waste water has potential environmental impacts due to the concentration of nutrients and other substances that require more oxygen to decompose. This is the largest source of liquid waste from ships, especially passenger ships. Estimates range from 120 to 320 liters per day for one person or 350 to 1,000 tonnes per day with a vessel carrying 3,000 people.

\section{Waste contamination}

Waste from the ship is made up of various materials such as mops, paper, cartoon paper, metal, glass, paint residues, cargo liners, food waste and cans or plastic materials. Many of these are burned and their ash is often discharged into the sea [24]. On average, each person on the ship leaves about 800 grams of garbage and 2 bottles of jars or cans each day [25]. With a passenger ship of several thousand people, the amount of garbage is enormous, according to the estimated amount of solid waste that comes from passenger ships, which account for $24 \%$ of all garbage from the world fleet.

\section{E. Pollution caused by the ship's anti-fouling system}

Because of the submergence of the ship always soaked in sea water should be a good adhesion to aquatic life including the sea. When hatching and growing on the hull surface, they significantly increase friction with water, slowing down ship speeds and increasing fuel consumption. To remove hatches to the hulls, metal-based paints and TBTs have been used as a toxic substance for the environment. During water dipping, the substance disperses slowly into the water and settles to the bottom causing poisoning to aquatic organisms. The new anti-pesticide pollution prevention convention is now being phased out of anti-fouling paint for ships.

\section{F. Pollution from ship emissions}

Most engines on board use diesel fuel for fuel. When burned in the engine, the emissions from the ship contain many environmental pollutants such as NOx and SOx that cause acid rain, $\mathrm{CO} 2$ causing greenhouse gases and ash contaminating the air [26]-[30].

\section{G. Pollution from ballast water}

In each ship's voyage, in order to ensure stability and balance for the vessel, water (sea, river, etc.) is pumped into the tanks on board, accompanied by ballast water that is the pathogen or aquatic organism present. In the area, when pumped into a new sea they may adapt to the environment in which they grow and overwhelm local ecological communities, resulting in ecological imbalance. regional or human health [31]. It is estimated that there are around 4,000 species worldwide, including phytoplankton, algae, fish, jellyfish and other invertebrates.

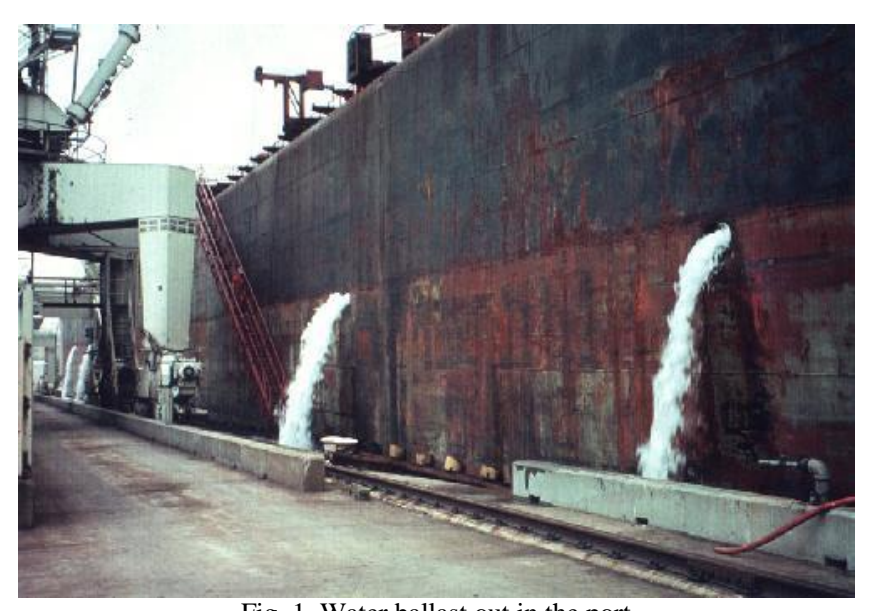

Fig. 1. Water ballast out in the port

Every hour, about 7.5 million liters of ballast water are discharged into the waters every hour, a marine specialist at the WWF Wildlife Fund. By transporting over $90 \%$ of the world's cargo, ocean freight transports around 10 billion tons of ballast water worldwide, and of course carries a lot of harmful organisms and pathogens. "When entering new waters, they can damage or even destroy the ecosystem of the sea. During the study, environmental scientists determined that the transport of organisms that hatch on the hull and in ballast water from one area to another has the potential to cause serious harm to the ecological environment. sea. These strange creatures can become invasive species, rapidly destroying local flora and fauna, causing serious damage to the ecosystem, the economy and even human health. 


\section{IMPACT OF ENVIRONMENTAL POLLUTION}

The environmental impacts of seaports vary from port location to port construction and maintenance activities, from port facilities to port facilities. They are loaded and stored at the port. Specific sources of environmental damage from seaports are numerous, including:

The circulation of road vehicles;

Waterways and railways;

Goods handling facilities;

Chemical storage and loading;

Providing fuel for ships, trucks, trains and freight vehicles;

Remove the liquid from the vessel;

Paint and hull cleaning;

Maintenance and repair of roads, railways, yards, boats, vehicles and equipment;

Dredge the canal.

Although seaports are often associated with heavy industry activities, they are often located in or near densely populated and ecologically sensitive areas, which often result in environmental consequences such as:

Air pollution from port activities and construction activities including pollution from fumes and dust;

Occupying or degrading the quality of submerged areas; destroy the fishing grounds;

Occupy the habitat of endangered species in the locality

Waste water discharged

Causing traffic congestion

Pollution caused by noise and light

Pollution of soil and water caused by leaks from tanks and pipelines

Steam is released from liquid chemicals

Create solid and toxic waste, drift, landslide.

In order to meet the growing demand for domestic and export fleets, many large shipyards have been upgraded, expanded and equipped with state-of-the-art technology and this has also increased coastal and marine pollution. From the shipbuilding and repairing process, the pollution is mainly heavy metal in the form of oxide powder such as lead oxide $\mathrm{Pb} 3 \mathrm{O} 4, \mathrm{~Pb} 2 \mathrm{O} 3, \mathrm{PbCrO} 3$, copper oxide powder, zinc oxide powder, $\mathrm{Fe} 2 \mathrm{O} 3, \mathrm{TiO} 2, \mathrm{ZnCrO} 3$; cellulosic paint $(-\mathrm{C} 3 \mathrm{H} 7 \mathrm{O} 2(\mathrm{OH}-)$ 2, epoxy $(\mathrm{CHOCH})$ paint, phenolic formaldehyde (-C6H5O-) paint, environmental alkyd ($\mathrm{CHO}$ ) paint. gasoline, fuel used much, causing considerable amount of waste oil in the construction phase. All heavy metals: $\mathrm{Zn}, \mathrm{Cu}, \mathrm{Hg}, \mathrm{Cr}$ are found in water and sediments, which are highly toxic, very stable and active metals in the marine organism, the food chain and its negative impact on human growth and health [32]-[35]. These wastes pollute mainly the coastal waters, oil pollution and sediment pollution (heavy metals) in the areas where shipyards and shipyards are located. These wastes alter the physicochemical properties of water, which directly affects aquatic and marine animals and plants as well as hinders the development of a number of marine industries, salt making, aquaculture and coastal torism.Boat repair also generates large amounts of dust when spraying sand or copper slag to clean the hull [36],[37]. This dust also contains many toxic chemicals for both humans and aquatic organisms. Asbestos dust, glass wool used in insulation on ships can persist for days in the human body, wading into the joints, accumulate in the pleural cavity is capable of causing cancer to humans. According to the statistics of Lloyd's Marine Information System, the world fleet of ships has nearly 100,000 registered and active in the world. The average life expectancy of ships is $25 \div 30$ years and when the service time expires, they will be demolished at a certain port. Every year, the number of old ships, the expiry of the use of demolition is increasing. According to Greenpeace estimates, by 2020 there will be about 5,000 ships demolished each year.

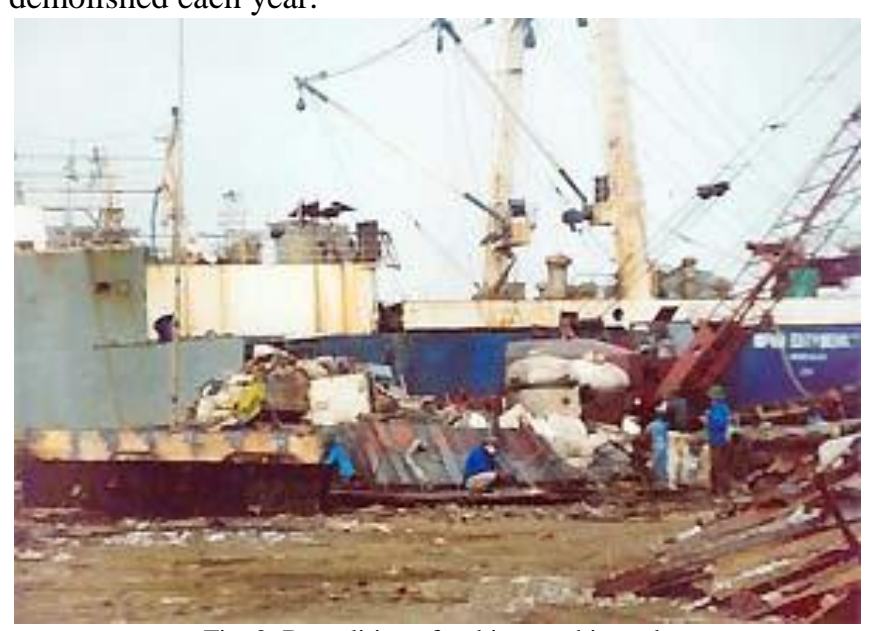

Fig. 2. Demolition of a ship at a shipyard

According to reports from international organizations such as the ILO, the Basel Convention, the demolition of sea-going vessels is likely to pollute the marine and inland environment caused by hazardous chemicals and wastes. as well as the risk of causing accidents to workers and surrounding communities by direct exposure to hazardous substances and dangerous incidents that may occur at any time. As most of the countries that receive ship dismantling are developing countries, heavily dependent on agriculture and fisheries, ship dismantling activities have a large and negative impact on the surrounding environment. Ship dismantlement activities threaten to seriously undermine fishery resources as well as affect the production of the fishery. Demolition ships produce toxic chemicals and hazardous waste such as PCB, PVC, PAH, TBT, mineral oil, asbestos, heavy metals (mercury, lead, copper, zinc, aluminum, iron. ..) and other hazardous substances such as radioactive substance, organic cyanide compound and ballast water ballast containing large amount of bacteria and foreign organisms [27]. That does not include the hazards of dismantling oil, chemical, radioactive, waste or other dangerous goods. Waste generated during ship dismantling: Most of the ships that need to be demolished in the current period are ships built in the 1970s. At that time no legal document banning the use of toxic chemicals was available. This has allowed manufacturers to use a lot of toxic substances such as:

The most toxic chemicals (as long as they are cheap) are able to protect the ship from being rusty, avoiding marine organisms (such as galaxies),

Use asbestos for good insulation and fire protection,

Light hull paint for easy identification of ships at sea in fog and to prevent ship hull erosion using paint containing lead and zinc chromate,

The paint contains antifouling agents such as mercury, 
arsenic, and tributyl tin (TBT) ... so that the hull can not gain weight by clinging to marine organisms.

According to calculations by some experts, $1 \mathrm{~m} 3$ of contaminated water will make $50-60 \mathrm{~m} 3$ of fresh water unusable. In the world, up to $500 \mathrm{~km} 3$ of polluted water is mixed with natural water on Earth every two years, leaving about 2 billion people without sanitary water. In spite of the country's attention to water resources, in 1950, the United States established a Water Resources Advisory Committee. In 1956, the International Commission on Water was established. However, industrialization is taking place at a rapid pace, and environmental protection measures are not strong enough, so the situation of water pollution is getting worse.

The achievements of global science and technology not only promote the industrialization of the continent, but the intensification of agricultural productivity is always improved. Annual agricultural output has been raised by the quality of seed and the use of pesticides. But this also has dire consequences for the environment and people, especially the herbicides. Research has found that the amount of pesticides, herbicides in water in some countries such as France reached 1.6-6.4 mg/l, the United States, some rivers pesticide content, kill Tall grass: DDT $11.3 \mathrm{mg} / 1$, Aldrin $5 \mathrm{mg} / \mathrm{l}$. The Detroit River provides up to 20 million tons of mixed waste each day, including pesticides, herbicides, kerosene and radioactive materials.

People also waste significant amounts of waste in the environment and this is one of the risks of surface water pollution. Analysis of water samples at 20 sites of 18 rivers in Kanagawa, Japan from 1987-1995 showed that $64.7 \%$ of samples were contaminated with V. cholerae, in Russia $98 \%$ of samples of Cama river water had E. coli 102 -104 / 100ml of water.

In parallel with improving the quality of treatment, hospital waste management in a number of hospitals in developed countries has been implemented in all health facilities. In Viet Nam, although the State and Ministry of Health have issued a series of laws and regulations such as the Law on the Protection of People's Health, the Law on Environmental Protection, the Regulation on infection of hospitals, medical waste .... But the management and treatment of hospital waste still exist. As many as $47 \%$ of hospitals do not have liquid waste treatment tanks, $15 \%$ of hospitals have liquid waste treatment systems but they are not functioning due to lack of maintenance funds. As such, hospitals do not have waste treatment systems, wastewater is discharged into the public sewer system. This will greatly contribute to microbial contamination from the hospital to the community where the effluent of the hospital flows. Garbage that is not classified but disposed of with domestic waste or buried at the hospital is also a factor causing environmental pollution.

Water pollution comes from many different causes. Because of receiving many types of waste water, surface water is polluted in many places, depending on the characteristics of different areas. However, due to the limitation in statistics, this section only mentions 4 main sources of waste that affect the surface water environment in Vietnam: agricultural, industrial, domestic and medical wastewater. Increasing levels of wastewater are now widespread in large parts of the country.

Domestic wastewater accounts for over $30 \%$ of total direct discharge to rivers, lakes or canals. According to calculations, the South East and Red River Delta are the two areas where most of domestic wastewater is concentrated. In the period of accelerated industrialization and modernization of the country, many industries are expanding their production scale as well as the distribution range. Along with the increase in the amount of wastewater, the investment in the wastewater treatment system is not up to the requirements. The South East region, with all the provinces in the Southern Key Economic Zone, where large industrial zones are concentrated, is the region with the largest amount of industrial wastewater. The number of industrial zones with wastewater treatment systems is still at medium level (50-60\%), moreover, $50 \%$ of them have not been effectively operated yet.

\section{CONCLUSION}

In order to meet the active ability of marine pollution prevention due to transport activities, we need to be main, but in case of emergency, we must be ready to respond and rescue in order to reduce the risk. ro due to breakdown. This requires us to study the application of new technologies to make products for oil spill mitigation using appropriate technology and materials. This paper contributes an important part in the process of applying science and technology into production practices, improving the effectiveness of environmental pollution prevention due to the operation of transport means. On the basis of new technologies for polymer adsorption on lignocenesulphonic polymers (straws) and applications for oil spills and heavy metals have been announced, combined with expert experiences. subjects and practical conditions to implement feasibility.

\section{REFERENCES}

[1] A. T. Hoang, Q. V. Tran, and X. D. Pham, "Performance and Emission Characteristics of Popular 4-Stroke Motorcycle Engine in Vietnam Fuelled with Biogasoline Compared with Fossil Gasoline,' no. 2, 2018 .

[2] A. T. H. Viet Dung Tran, Anh Tuan Le, Van Huong Dong, "Methods of operating the marine engines by ultra-low sulfur fuel to aiming to satisfy MARPOL Annex VI," Adv. Nat. Appl. Sci., vol. 11, no. 12, pp. 34-40, 2017

[3] A. T. Hoang and V. V. Pham, "Impact of jatropha oil on engine performance, emission characteristics, deposit formation, and lubricating oil degradation," Combust. Sci. Technol., 2018.

[4] L. Kuroshi and A. I. Ölçer, "A modified AD-TRIZ hybrid approach to regulation-based design and performance improvement of ballast water management system," J. Mar. Eng. Technol., pp. 1-13, 2018.

[5] Y. Yuan, Z. Li, R. Malekian, and X. Yan, "Analysis of the operational ship energy efficiency considering navigation environmental impacts," J. Mar. Eng. Technol., vol. 16, no. 3, pp. 150-159, 2017.

[6] A. O. Ifelebuegu and A. Johnson, "Nonconventional low-cost cellulose-and keratin-based biopolymeric sorbents for oil/water separation and spill cleanup: A review," Crit. Rev. Environ. Sci. Technol., vol. 47, no. 11, pp. 964-1001, 2017.

[7] V. V. Le, D. C. Nguyen, and A. T. Hoang, "The potential of using the renewable energy aiming at environmental protection," Int. J. Latest Eng. Res. Appl., vol. 2, no. 7, pp. 54-60, 2017.

[8] M. J. Wilson et al., "A targeted health risk assessment following the Deepwater Horizon oil spill: polycyclic aromatic hydrocarbon exposure in Vietnamese-American shrimp consumers," Environ. Health Perspect., vol. 123, no. 2, pp. 152-159, 2014.

[9] A. T. Hoang, "Waste heat recovery from diesel engines based on 
Organic Rankine Cycle,” Appl. Enery, vol. 231, pp. 138-166, 2018.

[10] N. Singkran, "Classifying risk zones by the impacts of oil spills in the coastal waters of Thailand," Mar. Pollut. Bull., vol. 70, no. 1-2, pp 34-43, 2013.

[11] A. T. Hoang, X. L. Bui, and X. D. Pham, “A novel investigation of oil and heavy metal adsorption capacity from as-fabricated adsorbent based on agricultural by-product and porous polymer," Energy Sources, Part A Recover. Util. Environ. Eff., vol. 40, no. 8, pp. 929939, 2018.

[12] A. A. Takshe, M. Huby, S. Frantzi, and J. C. Lovett, "Dealing with pollution from conflict: Analysis of discourses around the 2006 Lebanon oil spill," J. Environ. Manage., vol. 91, no. 4, pp. 887-896, 2010.

[13] S. T. Nguyen et al., "Cellulose aerogel from paper waste for crude oil spill cleaning,” Ind. Eng. Chem. Res., vol. 52, no. 51, pp. 18386 18391, 2013.

[14] B. D. Goldstein, H. J. Osofsky, and M. Y. Lichtveld, "The Gulf oil spill," N. Engl. J. Med., vol. 364, no. 14, pp. 1334-1348, 2011.

[15] M. Fingas, The basics of oil spill cleanup. CRC press, 2012.

[16] A. T. Hoang and M. Q. Chau, "A mini review of using oleophilic skimmers for oil spill recovery," J. Mech. Eng. Res. Dev., vol. 41, no. 2, pp. 92-96, 2018

[17] A. T. Hoang, V. V. Pham, and D. N. Nguyen, "A report of oil spill recovery technologies," Int. J. Appl. Eng. Res., vol. 13, no. 7, pp. 4915-4928, 2018.

[18] Anh Tuan Hoang et al., "An absorption capacity investigation of new absorbent based on polyurethane foams and rice straw for oil spill cleanup," Pet. Sci. Technol., vol. 36, no. 5, pp. 361-370, 2017.

[19] A. T. Hoang and L. Anh Tuan, "A review on deposit formation in the injector of diesel engines running on biodiesel," Energy Sources, Part A Recover. Util. Environ. Eff., 2018.

[20] A. T. Hoang, N. X. Chu, and T. Van Tran, "The Environmental Pollution In Vietnam: Source, Impact And Remedies," Int. J. Sci. Technol. Res., vol. 6, no. 2, pp. 249-253, 2017.

[21] A. T. Hoang and V. V. Pham, "A study of emission characteristic, deposits, and lubrication oil degradation of a diesel engine running on preheated vegetable oil and diesel oil," Energy Sources, Part A Recover. Util. Environ. Eff.

[22] T. A. Hoang and V. Van Le, "The Performance of A Diesel Engine Fueled With Diesel Oil, Biodiesel and Preheated Coconut Oil.," Int. J. Renew. Energy Dev., vol. 6, no. 1, 2017.

[23] A. T. Hoang, D. N. Nguyen, and V. V. Pham, "Heat Treatment Furnace For Improving The Weld Mechanical Properties: Design and Fabrication," Int. J. Mech. Eng. Technol., vol. 9, no. 6, pp. 496-506, 2018.

[24] A. T. Hoang and V. V. Le, "Marine pollution and remedies of Vietnamese Government," Int. J. Recent Eng. Res. Dev., vol. 2, no. 4, pp. 51-55, 2017
[25] D. N. Nguyen, A. T. Hoang, X. D. Pham, M. T. Sai, M. Q. Chau, and V. V. Pham, "Effect of $\mathrm{Sn}$ component on properties and microstructure Cu-Ni-Sn alloys," J. Teknol., vol. 80, no. 6, pp. 43-51, 2018.

[26] A. T. Hoang and V. T. Nguyen, "Emission Characteristics of a Diesel Engine Fuelled with Preheated Vegetable Oil and Biodiesel," Philipp. J. Sci., vol. 146, no. 4, pp. 475-482, 2017.

[27] A. T. Hoang, "The Performance of Diesel Engine Fueled Diesel Oil in Comparison with Heated Pure Vegetable Oils Available in Vietnam," J. Sustain. Dev., vol. 10, no. 2, p. 93, 2017.

[28] A. T. Hoang, M. M. Noor, and X. D. Pham, "Comparative Analysis on Performance and Emission Characteristic of Diesel Engine Fueled with Heated Coconut Oil and Diesel Fuel.," Int. J. Automot. Mech. Eng., vol. 15, no. 1, 2018.

[29] A. T. Hoang and V. T. Nguyen, "Emission Characteristics of a Diese Engine Fuelled with Preheated Vegetable Oil and Biodiesel," Philipp. J. Sci., vol. 4, no. 146, pp. 475-482, 2017.

[30] T. A. Hoang and V. Van Le, "The Performance of A Diesel Engine Fueled With Diesel Oil, Biodiesel and Preheated Coconut Oil," Int. J. Renew. Energy Dev., vol. 6, no. 1, p. 1, 2017.

[31] X. D. Pham, A. T. Hoang, D. N. Nguyen, and V. V Le, "Effect of Factors on the Hydrogen Composition in the Carburizing Process," Int. J. Appl. Eng. Res., vol. 12, no. 19, pp. 8238-8244, 2017.

[32] T. N. Le, M. K. Pham, A. T. Hoang, and D. N. Nguyen, "Microstructures and elements distribution in the transition zone of carbon steel and stainless steel welds," J. Mech. Eng. Res. Dev., vol. 41, no. 3, pp. 27-31, 2018.

[33] X. D. Pham, A. T. Hoang, and D. N. Nguyen, "A Study on the Effect of the Change of Tempering Temperature on the Microstructure Transformation of Cu-Ni-Sn Alloy," Int. J. Mech. Mechatronics Eng., vol. 18 , no. 4 , pp. 27-34, 2018

[34] M. K. Pham, D. N. Nguyen, and A. T. Hoang, "Influence of Vanadium Content on the Microstructure and Mechanical Properties of High-Manganese Steel," Int. J. Mech. Mechatronics Eng., vol. 18, no. 2, pp. 141-147, 2018.

[35] T. N. Le, M. K. Pham, A. T. Hoang, T. N. M. Bui, and D. N. Nguyen, "Microstructure change for multi-pass welding between austenitic stainless steel and carbon steel," J. Mech. Eng. Res. Dev., vol. 41, no. 2, pp. 97-102, 2018.

[36] A.T. Hoang, M.M. Noor, and X.D. Pham, "Comparative Analysis on Performance and Emission Characteristic of Diesel Engine Fueled with Heated Coconut Oil and Diesel Fuel," Int. J. Automot. Mech. Eng., vol. 15, no. 1, pp. 5110-5125, 2018.

[37] A. T. Hoang, "A Design and Fabrication of Heat Exchanger for Recovering Exhaust Gas Energy from Small Diesel Engine Fueled with Preheated Bio-oils," Int. J. Appl. Eng. Res., vol. 13, no. 7, pp 5538-5545, 2018. 